\title{
ACCESS TO FINANCE FOR ORGANIC PRODUCERS IN SERBIA: DEMAND SIDE ${ }^{1}$
}

\author{
Isidora Ljumović², Biljana Viduka ${ }^{3}$,Janko M. Cvijanovićc
}

\begin{abstract}
Summary
The aim of this paper is to identify the problems faced by organic producers when trying to access finance in Serbia. Previous research and experience show that demand for financial services in the segment of organic producers is higher than the supply, and that neither commercial banks nor other financial institutions are willing or able to meet financial needs within the value chain. Due to such situation, agricultural producers are stuck in the "missing middle" segment which lacks funding sources. This study uses questionnaires designed specifically to obtain farm-level data in order to evaluate the shortcomings of the farm credit system. The study shows that access to finance is one of the biggest constraints faced by organic producers and that the existing mechanisms for agricultural funding are not adequate.
\end{abstract}

Key words: Access to finance, organic production, bank loan.

JEL: $G 21,013, Q 14$

\section{Introduction}

In recent years, organic food has gained an increasing popularity worldwide and the demand for organic goods has never been higher. Following this trend, the cultivated land area under the organic production is growing on an annual basis. However, in Serbia and in the rest of the world, organic land still presents a small part of the total agricultural fertile land. On a global scale, organic production is interesting and important because it protects natural resources from pollution and preserves biodiversity. Also,

1 This paper is a part of the results within research on project 179001 financed by Ministry of Education and Science of the Republic of Serbia

2 Isidora Ljumović, Ph.D., Research Associate, Economic Institute, Kralja Milana street no. 16, 11000 Belgrade, Republic Serbia, Phone: +381 113613 029, E-mail: isidora.ljumovic@ecinst.org.rs

3 Biljana Viduka, M.Sc., Teaching Assistant, Technical College of Applied Science, Đorđa Stratimirovića street no. 23, 23000 Zrenjanin, Serbia, Phone: +381 23565 896, E-mail: biljana@,viduka.info

4 Janko M. Cvijanović, D.Sc., Principal Research Fellow, Economic Institute, Kralja Milana street no. 16, 11000 Belgrade, Serbia, Phone: +381 113613 029, E-mail: janko.cvijanovic@ecinst.org.rs

EP 2015 (62) 4 (989-1002) 
it provides long-term maintenance and enhancement of soil fertility. At the country level, it can ensure sustainable socio-economic rural development. For producers it is more cost effective to produce this type of products, because, despite lower yields, the margins are higher, and in addition they preserve the soil (Crowder, Reganold, 2015). At the consumer level, organic production provides safety.

As the consumption of organic food is growing, the current supply cannot meet the growing demand. Developing and transitional countries with optimal environmental conditions in rural areas have the opportunity to increase their supply of organic products on international market and thus boost profit without compromising the environment with dirty technologies, typical of these countries. However, access to finance and lack of affordable credit facilities represent a significant constraint to the further growth and sustainability of this sector (Jovanović, Despotović, 2012).

\section{Theoretical background}

Access to finance or availability of financial resources is one of the most important issues in the financial markets and the economy. Access to finance can be defined as the ability of individuals or companies to obtain financial resources and services. However, distinction has to be made between actual use of financial services and access to finance. Sometimes, individuals or companies simply do not approach the formal financial system because they have no need for it or do not wish to use its services. This is called voluntary exclusion from the formal financial system. The reasons for voluntary exclusion are different and include the habit of trading in cash, lack of interest in further investments or own funds sufficient to self-finance the projects. Involuntary exclusion from the formal financial system occurs when a person or a company wishes and needs to approach the system, but has no access to it due to a variety of reasons. The most common reasons are insufficient income, the lack of collateral or data from the credit registry, as well as high interest rates or risks (Ljumović et al., 2015).

Farmers are faced with the specific problems that could be grouped into three categories: seasonality, weather and environmental risks and market. Due to seasonality, organic produces are faced with challenges in managing their liquidity. Slow rotation of invested capital and irregular cash flow lead to irregular payment to creditors. Output and profitability of organic producers depend on the external risks - related to weather and environment, but above all on the temperature, variable rainfall, pests and diseases. Market challenges include price fluctuations or limited sale. Organic producers can have limited impact on some of these problems, but almost none of them can be controlled.

The agriculture in Serbia has favorable conditions for the development and represents an important factor in total national economy. Rural areas occupy large percentage of the territory of Serbia and are still characterized by a preserved natural environment and good conditions for the organization of crop and livestock production (Paraušić, Cvijanović, 2014). It is estimated that there are almost 230,000 ha of organic land in Serbia, where $96 \%$ is used for wild collection, primarily for harvesting berries, 
mushrooms and medicine herbs. The GTZ survey data show that the current organic production (until September 2013) was organized on around 7500 ha, including both areas under organic production and under conversion (National Association Serbia Organica, 2014). Currently, there are about 140 agriculture households involved in organic production, but more than $60 \%$ of them have less than 6 ha of land and $25 \%$ of them have 10-20 ha of land. Permanent crops are the most important, occupying almost 5000 ha, and are followed by permanent grassland (2500ha) and arable crops (1250ha). The sector of organic production is small, domestic-oriented, with rare or no connections between households, processors and other stakeholders. Cooperation between actors in the value chain is insufficient. However, the sector of organic production has been developing slowly, reporting each year an increasing number of farmers who are converting the land and joining the national system of organic production. The research related to the profile of organic consumers has identified high-frequency consumers who are expected to raise the demand for these products (Đokić et al., 2014).

\section{Literature review and hypotheses development}

Access to finance in the agriculture and organic production is identified as a limiting factor for development both in terms of fixed and variable inputs (Ciaian et al., 2012; Blancard et al., 2006; Gjosheva-Kovachevikj et al., 2013). If farm access to finance is limited, farms' input choices, productivity, and input use are constrained (Ciaian, Swinnen, 2009). Literature on access to finance in the agriculture and organic production in transitional countries is mainly focused on the supply side of the problem, usually including banks and microfinance institutions. Development organizations (USAID, EBRD, OECD) are mainly dealing with the constraints and statistics, while researchers are focused on the relationship between credit supply and farm productivity, farm inputs and outputs, investments and other aspects of rural development (for details see Swinnen, Gow, 1999; Swinnen, 2007; Latruffe, 2005; Latruffe et al., 2010). It is reasonable to expect that almost all studies have found positive relationship between an increased access to finance and improvement of analyzed parameters.

In the developed markets, farms can use different commercial financial sources (own resources, family and friends, foreign partners and integrators, bank loans, venture capital), but also various government development programs and grants or schemes of international institutions. Even though, at first glance, it seems that there are many financial institutions that provide financial resources in Serbia (the number of financial institutions offering credits, as compared to population and the number of enterprises, is relatively higher), the problem of access to finance is particularly evident in the segment of small and medium-sized enterprises and entrepreneurs (USAID, 2012; OECD, 2013). Access to finance in the agriculture and organic production is even more challenging than in the traditional business and is especially pronounced in countries with underdeveloped financial systems that do not have diverse financial institutions and do not provide a wide range of financial services. 
Banks in Serbia are the main source of credits for agriculture and organic producers. However, compared to other sectors, banks in Serbia invest only 3\% of their total loan portfolio in the agriculture (USAID, 2013). They provide finance to agriculture at the level lower than it would be anticipated, judging by the importance of this sector to the country's economy and GDP (Jolović et al., 2014). Formally, banks offer a wide-range of products to the agricultural sector - ranging from fertilizer/seed input financing, working capital loan, long-term investment financing (financing of agricultural processing equipment) and trade finance to special purpose loans, such as financial consolidation loans. However, all of these products are, generally, available only to big agricultural companies, but not to small farmers. Banks operating in Serbia are usually not suited to serve farmers due to the lack of knowledge in the agricultural sector and the lack of risk assessment capacity. Farmers and organic producers are often classified as highrisk clients and thus the interest rates are unfavorably high. Repayment terms are often mismanaged with farmers' cash flows, loan maturity is predominantly 2-3 years, while the grace period is often too long, making the credit more expensive, but ineffective. There is a mismatch of currency risk for agricultural and organic producers because borrowing takes place in foreign currency (euro) while most agricultural products are sold in local currency (dinar). Many organic producers are faced with a problem of accessibility of banking services. A small number of branches in Serbia operate in the rural environment. Farmers cannot approach a bank, at a branch office level, to get a loan (a survey on accessibility and the degree of satisfaction with banking services conducted by Marinkovic, Ljumović, 2010, reported relatively favorable situation in general, but with the caveat that distribution is uneven and unsatisfactory, especially in the rural areas).

Other financial institutions that are lending to the agriculture and organic producers include state funds, integrators, leasing companies and microfinance institutions. State funds are the second biggest lender to the agricultural sector with share of about $25 \%$ in total lending (USAID, 2013). Most active funds are the Serbian Development Fund, the Export Credit and Insurance Agency (AOFI), the Indemnity Fund of Serbia, the Vojvodina Guarantee Fund and the Vojvodina Provincial Fund for Agricultural Development. Although farmers may use the resources of all funds, the last three funds are specialized in agriculture.

The leasing sector, as well as the banking sector, recorded the highest growth in terms of total assets, but this sector is mainly focused on transport and automobile funding. Agricultural leasing is limited to tractors and combines and to investments in a small number of medium-sized equipment, thus arriving at an average of about $6-7 \%$ of the overall portfolio of all leasing companies (USAID, 2013).

Micro-finance institutions should be common creditors of agriculture. Unfortunately, in Serbia they are limited by the current regulatory framework as the Law on Banks does not allow for the establishment of credit institutions, except for banks and leasing companies that could directly provide loans to the agriculture or to any other business sector. This puts banks in the privileged position. Three private microfinance institutions 
in Serbia operate in LLP or NGO legal status. They cannot lend directly to the clients and they operate through the local banks, placing their cash assets in a bank account as collateral against loans made by the partner banks. Since they are forced to work with banks, microfinance institutions in Serbia have higher rates than banks, but strive to lend in local currency (Ljumović, et al., 2015).

Agriculture and agriculture financing is a politically sensitive issue since governments tend to intervene through several instruments: subsidies, loan quotas, incentives, credit support, rural economic development programs, etc. However, these programs are usually made ad hoc, from one budget year to another, and have a high degree of uncertainty. They depend on the current political situation and on the government, and they are not adjusted with long-term strategic goals of the agricultural policy.

In order to determine the funding sources available to organic producers and to explore the problems they face in Serbia when trying to access finance, we used a survey method. The hypotheses and survey were developed based on the interviews with organic producers and academics dealing with organic production. During the interviews, organic farmers stated that they started their activity for economic reasons and were satisfied, to a certain degree, with the results achieved. Nevertheless, they pointed out the constraints and the problems faced in the course of their activity. This is mainly related to the supply of inputs for organic production, distance from the market, marketing of the products, lack of qualified staff, lack of capital/subsidies for further investments and development. Other challenges include pest management, weed control, feeding, environmental constraints (poor quality of soil, water shortage, steep slopes, small parcels etc.), lack of available land around farmers' holdings, lack of knowledge on organic technology, lack of external assistance/extension services, lack of communication with the relevant Ministry and relevant authorities, especially when applying for subsidies, poor livelihood conditions/lack of asphalt roads, lack of infrastructure, lack of water supply, etc. having conducted the analysis, we have excluded environmental problems, sales market and government support measures, and we have designed the survey analyzing the problems of access to finance.

Based on our previous experience and interviews with the organic produces, we have formulated our hypotheses:

H1: Access to finance for the organic producers in Serbia is limited. They are usually financed from own capital or from a bank loan.

$\mathrm{H} 2$ : In theory of access to finance for the organic producers in Serbia, three groups of users can be identified.

H3: Most common external funding source, the bank loan, is not adjusted to the organic producers' needs.

Taking into account the defined hypotheses, the identified constrains and the literature review, we structured the questionnaires. For the purpose of data collection, structured questionnaires were originally scheduled to be distributed in two ways. The first one 
involved creation of a database of the organic farms' email addresses, and sending out email questionnaires. This method was less efficient and about $15 \%$ of sample was collected in this way. The second method involved previously scheduled meetings with farm owners and filling out of questionnaires on the spot, at the organic farms. To ensure reliability of the collected data, respondents were asked to provide personal data and the data on the contact person. Most of the respondents refused to give a permission to disclose the information about their farm in this research. Questions contained in the questionnaire were stipulated in a way that allows further processing and statistical analysis.

The questionnaire comprised two parts. In the first part, respondents gave answers to the questions on their personal data and on the data of the farm: name and address, type of registration, status of the farm, details about the certificate of organic farming and process of land conversion, main activity, number of employees, etc. The second part of the questionnaire contained questions on the farmers' opinion on access to finance and on identification of the problems they face with access to financial resources. Each question in the questionnaire was accompanied with a concise explanation in order to eliminate possible errors and ambiguities.

The survey covered the selected rural areas in the territory of the Republic of Serbia in places with the organic production. The study included 100 respondents in different stages of organic production (in the process of land conversion, not having started to produce organic products yet; a portion of the land converted; and conversion completed and the production started) and with different experience in access to finance. The response rate was 34\%. Even though the questionnaire contained no question on age, we gained the impression during the survey that the youngest respondents were most willing to cooperate. We were collecting the primary statistical material from November 2014 to February 2015. Table 1 shows basic characteristics of the sample.

The vast majority of respondents $(82 \%)$ are registered as a farm (as natural persons, pursuant to Serbian law). Regarding the question of ownership of the land they cultivate, they could choose multiple answers. They mainly cultivate their own land, but if they see profit they do not hesitate to rent the land from private entities or, if possible, from the state. Only $11.8 \%$ of respondents converted the entire land, while others are converting additional parts of the land or starting land conversion for the first time. The sample included farmers who have converted the land for the first time and have become organic producers, since they bear the highest costs and have the greatest need for financial resources. The question regarding activity was also a multiple-choice question, and the greatest number of producers declared themselves as fruit growers. 
Table 1. Frequencies of the basic characteristics of the sample

\begin{tabular}{|c|c|c|c|}
\hline Question & Answer & Frequency & Percent \\
\hline \multirow{3}{*}{ Registration } & Company & 4 & 11.8 \\
\hline & Entrepreneur & 2 & 5.9 \\
\hline & Farm & 28 & 82.4 \\
\hline \multirow{5}{*}{ Ownership } & Personal & 30 & $88.2 \%$ \\
\hline & $\begin{array}{l}\text { Rented from private } \\
\text { entities }\end{array}$ & 6 & $17.6 \%$ \\
\hline & $\begin{array}{l}\text { Private land you are } \\
\text { using for free }\end{array}$ & 0 & $0 \%$ \\
\hline & Rented from the state & 3 & $8.8 \%$ \\
\hline & $\begin{array}{l}\text { State land you are using } \\
\text { for free }\end{array}$ & 4 & $11.8 \%$ \\
\hline \multirow{2}{*}{ Total Land Conversion } & Yes & 4 & 11.8 \\
\hline & No & 30 & 88.2 \\
\hline \multirow{5}{*}{ Activity } & Fruit & 16 & $47.1 \%$ \\
\hline & Vegetable & 10 & $29.4 \%$ \\
\hline & Crops & 11 & $32.4 \%$ \\
\hline & Livestock & 4 & $11.8 \%$ \\
\hline & Other & 1 & $2.9 \%$ \\
\hline
\end{tabular}

Source: Authors' own calculation based on the survey

\section{Data analysis and results}

Data analysis was performed by using MS Office Excel and SPSS.

One of the purposes of this research was to examine whether organic producers are satisfied with the quantity and quality of the available sources of finance. After series of interviews in which organic farmers expressed discontent with sources of finance available to them, we decide to ask them a direct question as to whether the sources of finance are available to them to the extent necessary. Next question allowed us to identify funding sources which the organic producers can actually access and use. If research showed that organic producers use only some of the available resources that would mean that access to finance is poor.

Almost $60 \%$ of the respondents are not satisfied with the supply of funding sources. Also, when observing the range of available sources used by organic producers, it is evident that the scope of financial providers is very limited. Organic producers mainly use own funds and various government programs, including subsidies. 38\% of organic farmers covered by the research used bank loans. Interestingly enough, all organic producers who were surveyed left the field "Other (sources)" empty. Such results were expected because, in the previous interviews, respondents rarely specified other sources of financing than those listed in the questionnaire. When asked if they knew what integrators were, almost all of them responded positively, adding that even when they had cooperation (if any) with integrators, it was not in terms of financing. 
Value chain in organic production exists because the purchase of final products is sometimes guaranteed to organic producers (especially if they are located near processors), but they lack sources of finance in the early stages of production. When asked if they knew what venture capital was, none of those interviewed gave positive response, so this kind of financing was excluded from the survey. A majority of the organic producers are familiar with grants approved by international institutions, but they are not prepared (do not have the knowledge and skills) to apply for such grants.

Table 2. Survey results related to general attitude towards access to finance

\begin{tabular}{|l|l|r|r|}
\hline Question & Answer & Frequency & $\%$ \\
\hline \multirow{2}{*}{$\begin{array}{l}\text { Do you think that sources of finance } \\
\text { are available to you to the extent } \\
\text { necessary? }\end{array}$} & Yes & 2 & 5.9 \\
\cline { 2 - 4 } & No & 20 & 58.8 \\
\cline { 2 - 4 } & Partially & 12 & 35.3 \\
\hline \multirow{4}{*}{$\begin{array}{l}\text { What sources of finance have you } \\
\text { been using so far? }\end{array}$} & Own funds (equity, family and friends) & 26 & 76.5 \\
\cline { 2 - 4 } & Foreign partner & 5 & 14.7 \\
\cline { 2 - 4 } & Bank loan & 13 & 38.2 \\
\cline { 2 - 4 } & Various government development programs & 27 & 73.5 \\
\cline { 2 - 4 } & including subsidies & 0 & 0 \\
\cline { 2 - 4 } & Grants from international institutions & 0 & 0 \\
\cline { 2 - 4 } & Other & & \\
\hline
\end{tabular}

Source: Authors' own calculation based on the survey

Following the theory of access to finance, we have tried to distinguish between three groups of users: those that are using services, those that are voluntarily excluded and organic producers involuntarily excluded. After consideration of available financial sources, we have decided to make a distinction between organic producers based on their ability to apply for and get a bank loan, because bank loans are the biggest external source for organic farmers (38\%). Data referred to in Table 3 show three groups of users of the financial sources. The first group (38.2\% of respondents answered positively when asked whether they were using bank loans recently) includes users that have access to the financial system and use services. The second group comprises users who are voluntarily excluded (to the question regarding the reason for not using a loan, $23.5 \%$ of respondents answered "I did not need a loan" and $17.6 \%$ of respondents answered they had never applied for a loan). A more detailed analysis has shown that this group has the capacity to borrow from the financial system and it actually needs a loan, but has no confidence in the banking system or in the banking officers (this was the most frequent answer to the question why do not they use bank products), but opts for own sources of finance or for borrowing from friends, family or neighbors. Interestingly enough, respondents belonging to this group are willing to borrow from the bank if and when they regain confidence in the banking system, but according to their estimates there is a long way to go. Respondents who never applied consider the application process to be arduous and complex, they do not know how to apply or do not believe they will be granted a loan. The third group, involuntarily excluded organic produces $(17.6 \%$ of total respondents - those who applied for bank loans but were 
denied) cannot get loans because they are not in line with the bank policy or cannot find a guarantor. This third group is considered to be most vulnerable and requires urgent responses from policymakers, including a mix of measures designed to ensure that those involuntarily excluded have access to the financial services.

Table 3. Survey results related to problems in access to finance

\begin{tabular}{|c|c|c|c|c|}
\hline Question & Available answers & Frequency & Percent & $\begin{array}{r}\text { Valid } \\
\text { Percent }\end{array}$ \\
\hline \multirow{3}{*}{$\begin{array}{l}\text { Have you been using } \\
\text { bank loans recently? }\end{array}$} & Yes & 13 & 38,2 & 38,2 \\
\hline & No & 21 & 61,8 & 61,8 \\
\hline & Total respondents & 34 & 100 & 100 \\
\hline \multirow{5}{*}{$\begin{array}{l}\text { If you have not been } \\
\text { using bank loans } \\
\text { recently, please state } \\
\text { the reason why }\end{array}$} & I did not need it & 8 & 23,5 & 38,1 \\
\hline & I need a loan, but I have never applied & 6 & 17,6 & 28,6 \\
\hline & I applied, but I was denied & 6 & 17,6 & 28,6 \\
\hline & I had a loan, and I repaid it & 1 & 2,9 & 4,8 \\
\hline & Total respondents & 21 & 61,8 & 100,0 \\
\hline \multirow{4}{*}{$\begin{array}{l}\text { If you have never } \\
\text { applied for a loan, } \\
\text { please indicate why }\end{array}$} & I do not know how to apply & 2 & 5,9 & 33,3 \\
\hline & $\begin{array}{l}\text { The application process is arduous and } \\
\text { complex }\end{array}$ & 3 & 8,8 & 50,0 \\
\hline & $\begin{array}{l}\text { I do not believe that the bank will approve } \\
\text { me for a loan }\end{array}$ & 1 & 2,9 & 16,7 \\
\hline & Total respondents & 6 & 17,6 & 100,0 \\
\hline \multirow{7}{*}{$\begin{array}{l}\text { If you applied but } \\
\text { were denied a loan, } \\
\text { please indicate why }\end{array}$} & I have not yet repaid the previous loan & 0 & 0 & 0 \\
\hline & I cannot find a guarantor & 2 & 5,9 & 33,3 \\
\hline & I do not have a collateral & 0 & 0 & 0 \\
\hline & I have a bad credit history & 0 & 0 & 0 \\
\hline & $\begin{array}{l}\text { I was told I was not in line with the bank } \\
\text { policy }\end{array}$ & 4 & 11,8 & $\begin{array}{r}66,7 \\
0 \\
\end{array}$ \\
\hline & Due to personal reasons (e.g. bank officers) & 0 & 0 & 0 \\
\hline & Total respondents & 6 & 17,6 & 100,0 \\
\hline
\end{tabular}

Source: Authors' own calculation based on the survey

Taking into account that bank loans are the biggest external source (38\%), we have analyzed whether the bank loans meet the organic producers' needs (Table 4). Organic producers who have been using loans opted most often for special-purpose loans (agricultural loan, 85\%). If they use overdrafts, they use it on a personal basis, as natural persons. We did not identify any other bank products used by respondents. 
Table 4. Survey results related to the use of bank loans

\begin{tabular}{|c|c|c|c|c|}
\hline Question & Available answers & Frequency & Percent & $\begin{array}{r}\text { Valid } \\
\text { Percent }\end{array}$ \\
\hline \multirow{7}{*}{$\begin{array}{l}\text { Please specify the bank } \\
\text { products you have been } \\
\text { using (if any) }\end{array}$} & Special-purpose loans & 11 & 32.4 & 84.6 \\
\hline & Overdraft & 2 & 5.9 & 15.4 \\
\hline & Guarantees & 0 & 0 & 0 \\
\hline & Revolving Loans & 0 & 0 & 0 \\
\hline & A letter of credit & 0 & 0 & 0 \\
\hline & Other & 0 & 0 & 0 \\
\hline & Total respondents & 13 & 38.2 & 100.0 \\
\hline \multirow{4}{*}{$\begin{array}{l}\text { If you have been using } \\
\text { bank loans, do you think } \\
\text { they meet the needs of your } \\
\text { farm/company }\end{array}$} & Yes & 3 & 8.8 & 23.1 \\
\hline & No & 5 & 14.7 & 38.5 \\
\hline & \begin{tabular}{|l|} 
Partially \\
\end{tabular} & 5 & 14.7 & 38.5 \\
\hline & Total & 13 & 38.2 & 100.0 \\
\hline \multirow{5}{*}{$\begin{array}{l}\text { If your answer to the } \\
\text { previous question is NO } \\
\text { or PARTIALLY, please } \\
\text { indicate whether the loans } \\
\text { are adjusted in relation to... }\end{array}$} & Maturity & 2 & 5.9 & 20.0 \\
\hline & Terms of repayment & 3 & 8.8 & 30.0 \\
\hline & Collateral & 2 & 5.9 & 20.0 \\
\hline & \begin{tabular}{|l|} 
Other \\
\end{tabular} & 3 & 8.8 & 30.0 \\
\hline & Total & 10 & 29.4 & 100.0 \\
\hline \multirow{10}{*}{$\begin{array}{l}\text { What is the reason you } \\
\text { opted for a particular bank }\end{array}$} & Lowest interest rate & 3 & 8.8 & 23.1 \\
\hline & On the basis of previous experience & 4 & 11.8 & 30.8 \\
\hline & Easy procedure for loan approval & 0 & 0 & 0 \\
\hline & Personal relationships & 3 & 8.8 & 23.1 \\
\hline & Flexible loan terms & 1 & 2.9 & 7.7 \\
\hline & Good reputation & 0 & 0 & 0 \\
\hline & $\begin{array}{l}\text { The proximity and convenient } \\
\text { working hours }\end{array}$ & 1 & 2.9 & 7.7 \\
\hline & Random & 0 & 0 & 0 \\
\hline & Other & 1 & 2.9 & 7.7 \\
\hline & Total & 13 & 38.2 & 100.0 \\
\hline
\end{tabular}

Source: Authors' own calculation based on the survey

Organic producers who participated in this survey consider that bank loans do not meet their needs $(38.5 \%)$ or that they partially meet their needs (38.5\%). Only $23.1 \%$ of respondents who have been using bank loans think that loans meet their needs. Respondents are mainly unsatisfied with terms of repayment. Answers "Other" were also selected, and according to all the three answers, interest rate is the biggest problem when it comes to loans. We expected the interest rates to be the main criteria considered by the respondents when opting for a certain bank, but the survey has shown that only $23.1 \%$ of respondents choose a bank based on the lowest interest rate criteria. The main reason for this is previous experience and relations with the bank. It seems that personal relations also have big impact on the selection of a certain bank. At the time the survey was conducted, the number of loans not yet repaid by the organic producers who participated in the survey, ranged from 1 to 3 , i.e. the average mean was 1.27 . A 
majority of the organic producers had one loan at the time the survey was conducted. Interestingly enough, only four respondents were able to clearly indicate the amounts of interest rates. These amounts varied drastically from 3 to $16 \%$. We could not establish any regularity in this survey as to the question of banks which are most active in granting loans to organic farmers. Almost all banks in Serbia are equally represented regarding lending to organic producers, and only one stands out to a certain degree.

\section{Conclusion}

In this research, we have tried to identify the problems faced by the organic producers when trying to approach the formal financing system in order to provide necessary funding. Even at first glance, we can conclude that access to finance for the organic producers in Serbia is characterized by limited sources and government intervention with agricultural support measures.

After a series of consultations and interviews with the organic producers, we conducted a survey trying to reach all regions in Serbia where organic producers are present. The results point out that the hypotheses were properly set. There is an evident financial gap in the market for organic producers. Access to finance is poor and apart from own capital it is limited to bank loans and government subsidies. In the course of our interviews, the prevailing experience among the organic producers was that their borrowing is limited to bank loans, and therefore we focused on examining the terms and availability of bank loans. In this respect, the status of organic producers is very poor since more than $60 \%$ of respondents did not approach banking system. It is alarming that $17.6 \%$ of them are involuntary excluded from the system and cannot obtain external finance. The results on the adjustment of bank loans to the organic producers have indicated that there is no diversity of banking products and that organic producers use only few products. In addition, bank loans do not meet their needs regarding terms of payment, and a majority of organic producers think that interest rate is high. Commercial bank loans to the farmers and organic producers widely vary on the terms. However, the reason for this rests also with the fact that organic producers are accustomed to using government subsidies to a great extent, and this tends to weaken their attitude towards banks and the loan repayment culture.

This is one of the rare researches focusing on the demand side of access to finance in organic production. Further effort should be made to connect demand and supply in order to find the best solution for financing of organic production.

\section{Literature}

1. Bezemer, D. J. (2002): Credit markets for agriculture in the Czech Republic, Europe-Asia Studies Vol. 54, No. 8, pp. 1301-1317.

2. Blancard, S., Boussemart,J. P., Briec, W., Kerstens, K. (2006): Short- and LongRun Credit Constraints in French Agriculture: A Directional Distance Function Framework Using Expenditure-Constrained Profit Functions, American Journal 
of Agricultural Economics Vol. 88, No. 2, pp. 351-364.

3. Ciaian, P., Falkowski J., d'Artis, K. (2012): Access to credit, factor allocation and farm productivity: Evidence from the CEE transition economies, Agricultural Finance Review, Vol. 72, No.1, pp. 22-47.

4. Ciaian, P., Swinnen, J. F. M. (2009): Credit Market Imperfections and the Distribution of Policy Rents, American Journal of Agricultural Economics Vol. 91, No. 4, pp. 1124-1139.

5. Crowder, D. W., Reganold, J. P. (2015): Financial competitiveness of organic agriculture on a global scale, Proceedings of the National Academy of Sciences, Vol. 112, No.24, pp. 7611-7616.

6. Đokić, I., Đokić, N., Pavlović, N., Žnideršić-Kovač, R. (2014): Promocija organske hrane u Srbiji - implikacije istraživanja profila potrošača organske hrane, Ekonomika poljoprivrede, Vol. 61, No. 4, pp. 837-849.

7. Gjosheva-Kovachevikj, M., Kovachev, G., Risteski, H. (2013): Conditions and Perspectives of financial lending in Macedonian Agriculture and rural Development, in Book of Proceedings No. Fourth International Agronomic Symposium "Agrosym 2013”, pp. 1137-1142, University of East Sarajevo, Republic of Srpska, Bosnia and Herzegovina

8. Jolović, A., Njegovan, Z., Čavlin, M. (2014): Finansiranje poljoprivrede u Srbiji - stanje i perspektive, Ekonomika poljoprivrede, Vol. 61, No. 1, pp. 127-137.

9. Jovanović, M, Despotović, A. (2012): Analiza socio-ekonomskih uslova za bavljenje organskom proizvodnjom u Crnoj Gori, Ekonomika poljoprivrede, Vol. 59, No. 2, pp. 207-216.

10. Latruffe, L. (2005): The impact of credit market imperfections on farm investment in Poland, Post-Communist Economies Vol. 17 No. 3, pp. 349-362.

11. Latruffe, L., Davidova' S., Douarin, E., Gorton, M. (2010): Farm expansion in Lithuania after accession to the EU: The role of CAP payments in alleviating potential credit constraints, Europe-Asia Studies Vol. 62, No. 2, pp. 351-365.

12. Ljumović, I., Lazić, J., Vesić, A. (2015): Specifičnosti finansiranja u preduzetništvu, Ekonomski institut, Beograd, Srbija.

13. Marinković, S., Ljumović, I. (2010): Socijalna dimenzija pristupačnosti $i$ kvaliteta bankarskih usluga u Republici Srbiji, Ekonomika preduzeća, Vol. 58, No. 3-4, pp. 149-159.

14. National Association Serbia Organica. (2014): Organic Agriculture in Serbia At a Glance 2014, Belgrade, Serbia, Deutsche Gesellschaft für Internationale Zusammenarbeit (GIZ) GmbH, (available at: http://www.terras.org.rs/terras/ projekti/nesortirano/vesti\%202014/slike/Organic\%20agriculture\%20in \%20 Serbia-\%20At\%20a\%20Glance\%202014.pdf, last viewed 27.07.2015.).

15. OECD - Centre For Entrepreneurship, SMES and Local Developement. (2013): Financing SMEs And Entrepreneurs 2013: An OECD Scoreboard-Final Report, 
Paris, France, (available at: http://www.oecd.org/officialdocuments/publicdisplay documentpdf/?cote $=$ CFE/SME(2012)12/FINAL\&docLanguage $=$ En, last viewed 21.07.2015.).

16. Paraušić, V., Cvijanović, J.M. (2014): Konkurentnost agroprivrede Srbije, Institut za ekonomiku poljoprivrede, Beograd, Srbija.

17. Swinnen, J. F. M. (2007): The dynamics of vertical coordination in agri-food supply chains in transition countries ch. No. 4, pp. $42-58$ in Global Supply Chains, Standards and the Poor, CABI, Oxon, Sao Paolo, Brazil.

18. Swinnen, J. F.M., Gow, H. R. (1999): Agricultural credit problems and policies during the transition to a market economy in Central and Eastern Europe, Food Policy Vol. 24, No.1, pp. 21-47.

19. USAID (2012): Financing the Growth of Small and Medium Sized Enterprises Critical Issues and Recommendations for Serbia, Belgrade, Serbia, (available at http://www.bep.rs/documents/c3/FINANCING\%20THE\%20GROWTH\%20 OF\%20SME\%20-\%20Critical\%20Issues\%20and\%20Recommendations.pdf, last viewed on 08.07.2015).

20. USAID (2013): Business Enabling Project - Agricultural Finance in Serbia - Status and Recommendations, Belgrade, Serbia, (available at http://www. policycafe.rs/documents/financial/research-and-publications/commodity-marketdevelopment/Agricultural\%20Finance\%20in\%20Serbia.pdf, last viewed on 10.07.2015). 


\title{
PRISTUP FINANSIJSKIM RESURSIMA ORGANSKIH PROIZVOĐAČA U SRBIJI: ANALIZA TRAŽNJE
}

\author{
Isidora Ljumovićs, Biljana Viduka ${ }^{6}$,Janko M. Cvijanovic ${ }^{7}$
}

\begin{abstract}
Sažetak
Cilj ovog rada je identifikacija problema sa kojima se organski proizvođači u Srbiji suočavaju prilikom pribavljanja finansijskih sredstava. Ranija istraživanja i dosadašnje iskustvo pokazuju da je u segmentu organskih proizvođača veća tražnja za finansijskih resursima od ponude, te da poslovne banke i ostale finansijske institucije ne žele ili ne mogu da zadovolje finansijske potrebe u lancu vrednosti. Zbog ovakve situacije poljoprivredni proizvođači se nalaze u takozvanom srednjem segmentu kome nedostaju izvori finansiranja. Da bismo dobili konkretne podatke od organskih proizvođača, kreirali smo upitnike kako bismo procenili nedostataka sistema kreditiranja poljoprivrednika. Istraživanje pokazuje da je pristup finansijama jedno od najvećih ograničenja sa kojima se organski proizvođači suočavaju i da postojeći mehanizmi za finansiranje nisu adekvatni.
\end{abstract}

Ključne reči: pristup finansijama, organska proizvodnja, bankarski kredit

5 Dr Isidora Lj. Ljumović, naučni savetnik, Ekonomski institut, Kralja Milana br. 16, Beograd, Srbija, Telefon: +381 113613 029, E-mail: isidora.ljumovic@ecinst.org.rs

6 Asistent, mr Biljana Z. Viduka, Visoka tehnička škola strukovnih studija, Đorđa Stratimirovića br. 23, Zrenjanin, Srbija, Telefon: +38123565 896, E-mail: biljana@viduka.info

7 Profesor, dr Janko M. Cvijanović, naučni savetnik, Ekonomski institut, Kralja Milana br. 16, Beograd, Srbija, Telefon: +381 113613 029, E-mail: janko.cvijanovic@,ecinst.org.rs

EP 2015 (62) 4 (989-1002) 